\title{
A city and its people: Canberra in the Australian Dictionary of Biography ${ }^{1}$
}

KAREN FOX

A search of the Australian Dictionary of Biography $(A D B)$ and the associated websites that make up the People Australia portal produces remarkably few individuals born in Canberra: just eight as of May 2019. ${ }^{2}$ To some extent, the shortage of Canberraborn figures in the $A D B$ and its companion websites is a consequence of the city's relatively recent founding, chosen as the future capital of the Commonwealth of Australia in 1908 and officially named in a ceremony a little more than 100 years ago. Designed and constructed to be the country's capital, Canberra has been a city of immigrants. It is likely that the numbers of individuals born in Canberra whose stories are told in these websites will increase dramatically in the future, partly thanks to additions planned to the websites, but also reflecting the significance of the city's role as Australia's capital in the twentieth century and beyond. Despite the small numbers of Canberra-born, however, the People Australia websites include a wide array of people who have lived, worked, loved and fought in the Canberra district. In this essay, I explore Canberra's history through some of the people who have shaped it, with a focus on those whose stories are told in the $A D B$ and its associated websites.

\section{Founding of Canberra}

As a capital city, Canberra's history is relatively short. The land on which it stands, however, has been inhabited and tended for thousands of years. Archaeological evidence shows that there has been habitation in the area for over 20,000 years. Rock painting at locations such as Yankee Hat, campsites and rock shelters like

\footnotetext{
1 This essay was originally prepared for Canberra's centenary celebrations in 2013, and published online for the Australian Dictionary of Biography and in Using Lives: Essays in Australian Biography and History, vol. 1, no. 1 (2014), adb.anu.edu.au/essay/7. It appears here largely as written, with minor revision to bring it up to date.

2 They are: politician John MacPherson; Mary Cavanagh, the widow of local resident Patrick Cavanagh; James Benjamin Sibrey, who later lived in north-west New South Wales; Amelia Alice McIntyre, who is listed in People Australia but for whom there is as yet no associated entry; shearer Michael Scannell; forester Ray Margules; St John Ambulance chief executive officer Charles Campbell; and musician Barnaby Ward. The search was conducted on 10 May 2019 using the 'Advanced Search' function on the People Australia website: peopleaustralia.anu.edu.au/ advanced-search/.
} 
that at Birrigai, ochre quarries at Red Hill and in the Gungahlin area, and stone tools found around the district are among the traces that testify to a rich history of habitation by Aboriginal people. ${ }^{3}$

European settlers first arrived in the area in the 1820s, following exploration in search of the Murrumbidgee River by Charles Throsby, a surgeon and settler, and Joseph Wild, an emancipist in Throsby's employ. The first European to claim land in the district was Joshua John Moore, an absentee landlord who took up 1,000 acres at a location he referred to as 'Canbery'. Not long after, James Ainslie brought sheep to the area and stocked 4,000 acres of land for Robert Campbell. ${ }^{4}$ Increasing his holding, which he called Duntroon, by the 1840s Campbell held 'the choicest selections' on the Limestone Plains, as the area was known. ${ }^{5}$ Later, one of Campbell's sons, Charles, would provide for the building of a church and a school at Duntroon; the church, that of St John the Baptist in Reid, is still an important part of Canberra life. Other landholders soon joined Moore and Campbell. In a census taken in November 1828, three stations besides Duntroon and Canberry were listed at or near the site that would become Canberra: Ginninderra (held by George Thomas Palmer), Jerrabomberra (John Palmer) and Quinbean (Timothy Beard). The first resident landholder in the district was John MacPherson, who named his land Springbank. His children Helen, born in 1830, and John Alexander, born in 1833, were claimed to be the first non-Indigenous children born in the region. ${ }^{6}$

Further European settlers arrived in the 1830s, and by the middle of the decade much of the good pastoral land in the area had been parcelled out in government grants. The locality had a postal service, in Queanbeyan, from 1836, and that same year its first doctor, William Foxton Hayley, arrived and started a practice. In 1838 a police magistrate, Alured Tasker Faunce, was appointed, and the first resident minister of religion, Anglican priest Edward Smith, arrived in Queanbeyan. ${ }^{7}$ Small villages and towns grew up around the station properties, and the European population of the region, including both free settlers and assigned convicts employed by landholders, gradually increased. Local Aboriginal people could sometimes camp on or near the stations, and were thus able to remain on their own land. Some worked as guides or stockmen, as did Johnny Taylor, who had grown up on the Ginninderra

\footnotetext{
3 Josephine Flood, Moth Hunters of the Australian Capital Territory: Aboriginal Traditional Life in the Canberra Region (Canberra: J. M. Flood, 1996), 3, 28-33; Josephine Flood, 'Aboriginal Sites Around Canberra', Bogong 4, no. 3 (September-October 1983), 10-11. The 'mute witness' such evidence gave to 'a long-continued occupation' was recognised in the Canberra Times in 1931. 'Aboriginal Art in the Territory', Canberra Times, 30 October 1931, 4.

4 Lyall Gillespie, Canberra: 1820-1913 (Canberra: Australian Government Publishing Service, 1991), 1-10.

5 Margaret Steven, 'Campbell, Robert (1769-1846)', Australian Dictionary of Biography, National Centre of Biography, The Australian National University, adb.anu.edu.au/biography/campbell-robert-1876/text2197, accessed 3 July 2013.

6 Gillespie, Canberra: 1820-1913, 15, 18; Dorothy Fitzpatrick, 'MacPherson, John Alexander (1833-1894)', Australian Dictionary of Biography, National Centre of Biography, The Australian National University, adb.anu.edu. au/biography/macpherson-john-alexander-4135/text6621, accessed 3 July 2013.

7 Gillespie, Canberra: 1820-1913, 23, 75.
} 
station, and who was one of the Ginninderra cricket team's finest players in the 1860s and 1870s. ${ }^{8}$ The district gained direct parliamentary representation in 1843, when the first elections for the New South Wales Legislative Council were held; (Sir) Terence Murray, who held land at Yarralumla (now the site of Government House), was elected unopposed.

By the middle of the century, the European population of the region had grown considerably. The landscape had been substantially altered by clearing for cultivation and construction, stock grazing and the shooting of native wildlife. New waves of European arrivals intensified the struggle for survival faced by local Aboriginal people, who were contending with the pressures of disease, dislocation, hostility from those who had invaded their lands and loss of resources. ${ }^{9}$

The 1860 s were a 'turbulent' decade in the Canberra region. ${ }^{10}$ Among other developments, a revival of bushranging occurred, possibly stimulated by discoveries of gold deposits in the area. Most notorious were the 'Jingera Mob', who based themselves near Captains Flat and conducted robberies and hold-ups around the locality, including of the Queanbeyan-Sydney mail coach and stores at Gundaroo and Michelago. The gang's activities were largely brought to an end with the capture of Thomas and John Clarke, two of the ringleaders, in 1867, and bushranging once more declined. ${ }^{11}$ A large number of new selections were occupied during the $1870 \mathrm{~s}$ and 1880s. Large properties in the region generally bred sheep, with some also grazing cattle, while grain was mostly grown by free selectors with smaller holdings. ${ }^{12}$ One local grain-grower who became well-known was William Farrer, the son-in-law of Leopold Fane de Salis of Cuppacumbalong. Once a tutor to the Campbell family at Duntroon, Farrer later experimented with wheat breeding at Lambrigg, along the Murrumbidgee River, eventually succeeding in producing wheat varieties that had increased resistance to rust.

As the twentieth century dawned in the district, its small centres were mostly 'well organised, with thriving churches, schools, and various sporting clubs and associations'. ${ }^{13}$ The area was emerging from a period of severe depression during the 1890 s, and was soon to gain a new importance as the seat of the federal government, the result of a decision at the 1899 premiers' conference that a capital city for

8 Ann Jackson-Nakano, The Kamberri: A History of Aboriginal People in the ACT and Surrounds, Aboriginal History Monograph 8 (Canberra: Aboriginal History, 2001), 105, 123; Gillespie, Canberra: 1820-1913, 34, 59; 'Local and District News', Queanbeyan Age, 28 January 1869, 2; 'Local Items', Newcastle Chronicle, 9 February 1869, 3.

9 Flood, Moth Hunters, 40-41; Gillespie, Canberra: 1820-1913, 42-44; Jackson-Nakano, The Kamberri, 105, 108-67.

10 Gillespie, Canberra: 1820-1913, 127.

11 Gillespie, Canberra: 1820-1913, 134-37; Lionel Wigmore, Canberra: History of Australia's National Capital (Canberra: Dalton Publishing Company, 1972), 21; 'Capture of the Bushrangers Thomas and John Clarke', Sydney Morning Herald, 4 May 1867, 5.

12 Gillespie, Canberra: 1820-1913, 155, 159, 171.

13 Gillespie, Canberra: 1820-1913, 73-74, 217. 
the new Commonwealth of Australia should be located in New South Wales, no less than 100 miles from Sydney. It took a considerable time, and much debate, before the Canberra site was selected, however. In late 1899 Alexander Oliver was commissioned to enquire into the choice of a suitable site. Considering a range of factors, including accessibility, water supply and climate, he examined 23 potential locations. When he made his recommendations in October 1900, his preference was for Bombala, although he also suggested the Yass-Canberra area and the city of Orange as possibilities. ${ }^{14}$

There followed a fierce struggle over the matter. At Sir William Lyne's instigation, federal parliamentarians visited a number of nominated sites; the press indulged in much mirth at this 'distinguished picnic ... progressing at hurricane speed through the country' and, when Lyne later planned visits to other parts of the new Commonwealth, he found himself dubbed the 'Minister for Picnics'. ${ }^{15}$ A royal commission was established by the new Commonwealth Government; chaired by an architect, John Kirkpatrick, it recommended the city of Albury in 1903. Disagreement and conflict over the question of the new capital's location continued, however, with first one and then another city seeming to be in the ascendancy. Not until 1908 was agreement reached that the site should be the Yass-Canberra region, after a vigorous campaign in favour of the site was waged by the Queanbeyan Federal City Committee. Local community leaders who were influential in the choice of Canberra included the owner of Yarralumla station, Frederick Campbell; newspaper proprietor John Gale; politician (Sir) Granville Ryrie; Andrew Jackson Cunningham, of Lanyon station, and his brother James, of Tuggranong; and later politician (Sir) Austin Chapman. ${ }^{16}$

\section{Canberra becomes the seat of federal government}

Following the choice of Yass-Canberra, the area was surveyed by Charles Scrivener, and an agreement as to the extent of the capital territory was reached between the prime minister, Alfred Deakin, and the premier of New South Wales, Sir Charles Wade. The new territory was declared in January 1911. Shortly after, a competition to design the capital city opened, with proposals invited from around the world and a first prize of $£ 1,750 .{ }^{17}$ The entries were considered by a committee chaired

14 Wigmore, Canberra, 26; Jim Gibbney, Canberra 1913-1953 (Canberra: Australian Government Publishing Service, 1988), xiii; 'The Site of the Federal Capital', Sydney Morning Herald, 31 October 1900, 8.

15 'The Federal Capital', Evening News (Sydney), 14 February 1902, 4; 'The "Minister for Picnics"', Register (Adelaide), 18 November 1902, 5.

16 On the campaign, see Susan Mary Woolcock Withycombe, Gale Force: John Gale and the Siting of the National Capital (Queanbeyan: Queanbeyan \& District Centenary of Federation Committee Inc., 2001).

17 Wigmore, Canberra, 49. 
by John Coane, which reported to Home Affairs minister King O'Malley as adjudicator. O'Malley's role was strongly criticised, as he held no relevant professional qualifications, and, after he declined to yield on the matter, a boycott of the competition was instigated by the Royal Institute of British Architects, the Institute of Civil Engineers and affiliated organisations. ${ }^{18}$ Nevertheless, more than 100 entries were received. The winner was announced in May 1912; it was the work of American architect Walter Burley Griffin and his wife Marion Mahoney Griffin. In the meantime, the first Commonwealth facility in the territory, the Royal Military College at Duntroon, had already opened; soon-to-be military hero (Sir) William Throsby Bridges was its first commandant, and its instructors included Henry Macartney and Harold Chumleigh.

Opposition to the Griffins' design as overly complicated and too expensive led O'Malley to refer it to a departmental board of experts, who recommended a mishmash of the four top-placing designs. Having presented this recommendation to parliament, O'Malley initiated work on the new capital. The first foundation stones were laid, using golden trowels, by the governor-general, Lord Denman, the prime minister, Andrew Fisher, and O'Malley on 12 March 1913 at a ceremony attended by official guests including former prime minister Chris Watson and future prime minister Billy Hughes. At this occasion the name of the new capital was revealed. It had been selected from several hundred possibilities suggested by the public, which ranged from the striking to the ridiculous; among the offerings were 'Austral', 'Wattleton', 'Federalia', 'Eucalypta' and 'Cookaburra'. ${ }^{19}$ Following the laying of the foundation stones, the governor-general's wife, Lady Denman, took the name from an inscribed gold card case and declared it to be 'Canberra'. ${ }^{20}$

A few months later, the Griffin plan was reinstated as the blueprint for the new city, following a change of government. The new prime minister, Joseph Cook, gave responsibility for the Federal Capital Territory to William Kelly, who was minister without portfolio in his government. Griffin, who had been unhappy with the proposed changes to his design, was appointed federal capital director of design and construction. Soon, however, he was embroiled in conflict with officials, including the new resident administrator of the territory, David Miller, who had chaired the departmental board that recommended the discarding of his design, and the director-general of works, Percy Owen. This, together with the outbreak of World War I in 1914, greatly delayed progress on the new capital. A royal commission, conducted by Wilfred Blacket, investigated the situation, and in 1917 expressed support for Griffin. Only a few years later, however, the government determined

\footnotetext{
18 Wigmore, Canberra, 51.

19 Wigmore, Canberra, 57; Gillespie, Canberra: 1820-1913, 249; Campbell Phillips, 'On This Day: Australia’s Capital City Named', Australian Geographic, 12 March 2013, accessed 28 May 2013, www.australiangeographic. com.au/blogs/on-this-day/2013/11/on-this-day-australias-capital-city-named/.

20 Wigmore, Canberra, 57.
} 
that Griffin should not continue to act as director of design and construction; his employment ceased in late 1920, and he reluctantly took no further part in the city's development. ${ }^{21}$

A Federal Capital Advisory Committee was appointed, headed by (Sir) John Sulman; its secretary was Charles Studdy Daley. The committee began meeting in 1921. Unable to support the expenditure necessary to bring 'ideas of monumental grandeur' into being because of the impact of spending during the war, the committee adopted a two-stage approach, in which simple, utilitarian buildings would be erected, later to be gradually replaced with more permanent, and more imposing, structures. ${ }^{22}$ The committee was succeeded by the Federal Capital Commission (FCC), with (Sir) John Butters at its head; it held its first meeting in November 1924. The BrucePage Government decided that the next government would meet in Canberra, and the commission was given the task of ensuring that Canberra was ready for parliament and public servants to arrive there in $1927 .{ }^{23} \mathrm{~A}$ month later the new city gained its own newspaper. The Federal Capital Pioneer was produced by Alexander Murray, and announced its arrival as 'the first newspaper printed and published on Federal City Territory' in December $1924 .{ }^{24}$ The paper appeared weekly until October 1926, when it was transformed into a historical magazine under pressure of competition from the Canberra Times, founded by Thomas Shakespeare and edited by his son Arthur; Murray was later proclaimed missing in Britain, having arrived in London to establish a claim to a baronetcy. ${ }^{25}$

Canberra grew rapidly as the moment for the arrival of the federal parliament drew nearer. Three hundred and seventy-one plans for shops, schools, houses or non-government offices were approved in 1926-27. ${ }^{26}$ The construction workforce living in the area increased, with large numbers of labourers living in tent camps and shanty towns as well as in workers' cottages erected for their accommodation. Among the residents of the camps was Lewis Lasseter, who later excited the hopes of gold-seekers with his claim that he had discovered an immense gold-bearing reef in Central Australia. ${ }^{27}$ Many new buildings were completed, including hotels, offices, houses, a picture theatre and a community hall. In October 1926 a statue of the King, George V, reached Canberra, and was stored in a large case in Parliament House in preparation for its erection. ${ }^{28}$ Ten days later the first public servant transferred from Melbourne: J. F. C. Whittle, arrived with his wife and they lived in a hotel until

\footnotetext{
Gibbney, Canberra 1913-1953, 29-43; Wigmore, Canberra, 78.

Gibbney, Canberra 1913-1953, 66.

Gibbney, Canberra 1913-1953, 98, 111-12.

Federal Capital Pioneer, 3 December 1924, 1.

Gibbney, Canberra 1913-1953, 105; 'Missing Mr A. K. Murray', Canberra Times, 14 January 1929, 1.

Wigmore, Canberra, 97.

Gibbney, Canberra 1913-1953, 114.

'King's Statue', Canberra Times, 1 October 1926, 1.
} 
a house was ready for them. ${ }^{29}$ The Duke of York opened the provisional Parliament House, designed by John Smith Murdoch, at a ceremony on 9 May 1927 at which Dame Nellie Melba sang the national anthem. The city centre was officially opened by the prime minister, Stanley Bruce, in December.

Not all of Canberra's residents were happy with their new home. Plagued by dust when it was sunny, mud when it was raining and innumerable flies, as well as being deprived of the vote in either state or federal elections by their move to the capital territory, many were discontented. ${ }^{30}$ Determined and creative inhabitants worked hard to create a community, alleviating the discomfort. Residents came together in a variety of organisations and activities. Sir Robert Garran, the Commonwealth solicitor-general, became the first president of the Canberra Society of Arts and Literature and was vice-president of the Canberra Musical Society. His wife Lady Garran and her friend Pattie Tillyard, who was the wife of Robin Tillyard, a scientist at the Council for Scientific and Industrial Research, welcomed new arrivals. A musical group called the Stromberra Quintet was formed, including among its members Walter Duffield, the first director of the Commonwealth Solar Observatory on Mount Stromlo, and his wife Doris; the quintet participated in an event billed as Canberra's 'first Philharmonic concert' on 15 May 1926. ${ }^{31}$ The Sydney Morning Herald reported in December 1927 that the city had 'become a centre of gaiety', with parties held by Lady Groom, the wife of the Speaker of the House of Representatives, Sir Littleton Groom; Penelope Gullett, the wife of the member for Henty, (Sir) Henry Gullett; and Lucie McLaren, the wife of the secretary of the Department of Home and Territories, (Sir) John McLaren. ${ }^{32}$ Ruth Lane-Poole, who designed and furnished the interiors for the Prime Minister's Lodge and Government House, was an ardent promoter of Canberra and took a prominent role in developing the city's cultural and social life; her husband, Charles, was acting principal of the Australian Forestry School.

\section{Canberra in depression and war}

Almost immediately after the opening of Parliament House, the workforce employed in the construction of Canberra began to be cut. The number of people employed in the task shrank from 3,086 in January 1927 to 1,018 in October 1928, and many of the workmen's camps were closed or torn down. ${ }^{33}$ Matters were not improved by the advent of the Great Depression. With a population of less than

\footnotetext{
29 Gibbney, Canberra 1913-1953, 124; 'First Transfer from Melbourne for National Library', Canberra Times, 14 October 1926, 9.

30 Wigmore, Canberra, 109-11.

31 'The First Philharmonic Concert at Canberra', Federal Capital Pioneer (Canberra), 25 June 1926, 2.

32 'Social Life at Canberra', Sydney Morning Herald, 13 December 1927, 5.

33 Gibbney, Canberra 1913-1953, 142.
} 
7,000 people, Canberra's development stagnated. Work was halted on the Australian War Memorial, the building of which had been advocated by Charles Bean, the official historian of World War I. Construction did not resume until 1933, and the memorial was not opened until 1941. Planned transfers of public servants from Melbourne were cancelled, and public building projects largely halted. ${ }^{34}$

As the Depression eased in the second half of the decade, a revival began in the new capital. A new advisory body, the National Capital Planning and Development Committee (NCPDC), was created to oversee Canberra's development in 1938, and the same year the territory was renamed the Australian Capital Territory (ACT). The city's growth was soon threatened again, however, when war was declared in September 1939. Much important government business was located in Melbourne or Sydney during the war, and Canberra's position as the national capital somewhat diminished. The dispersal of government functions between Canberra, Melbourne and Sydney caused politicians and public servants to have to travel continually between the three centres. ${ }^{35} \mathrm{~A}$ tragic outcome of this constant travel was the deaths of three cabinet ministers, the chief of the general staff and several others when a Royal Australian Air Force Hudson crashed on its approach into Canberra on 13 August 1940. Among the victims were Geoff Street, the minister for the army and for repatriation; Jim Fairbairn, the minister for air; Gullett, the vice-president of the executive council; and Sir Brudenell White, the chief of the general staff. The Canberra Times described the accident as a 'severe blow to [the] war administration', with 'the proportions of a national disaster'. ${ }^{36}$

With the war's end in 1945, Canberra faced new difficulties, among them growing pressure on housing and shortages of labour and materials. (Sir) Bill Dunk, appointed head of the Public Service Board in 1947, stated the following year that housing shortages were restricting the abilities of departments to transfer their officers to Canberra. He also commented on the necessity for the city to provide for young people and to 'progress culturally', citing in particular need for a theatre. ${ }^{37}$ Plans were made to move successive government departments to Canberra, some within three years and others in stages within 10 years, but nevertheless delays continued. ${ }^{38}$ In some areas, however, progress occurred relatively quickly after the war. The project to establish a university in Canberra, first recommended in 1927 by a committee that included Sir Mungo MacCallum, Lyndhurst Giblin and (Sir) Robert Wallace, bore fruit. While tertiary education had begun in 1930 with the establishment of Canberra University College as an associated college of the University of Melbourne-an institution keenly supported by prominent Canberra

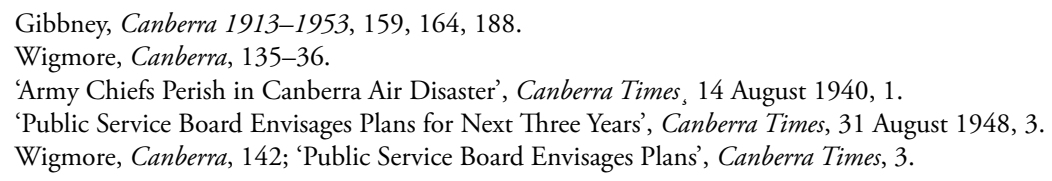


resident (Sir) George Knowles - the Depression had ended hopes for a national research university. ${ }^{39}$ In 1946, however, The Australian National University was founded, with four research schools and an academic advisory committee of eminent individuals who were envisaged as prospective directors for the schools: Sir (later Lord) Howard Florey (medical research), (Sir) Mark Oliphant (physical sciences), (Sir) Raymond Firth (Pacific studies) and (Sir) Keith Hancock (social sciences). Community building efforts continued as well. With other Canberra women, Yseult Bailey, the wife of (Sir) Kenneth, worked to establish preschool education in the capital; she was later president of the ACT branch of the National Council of Women.

\section{Growth and development}

In the early 1950s, Canberra remained relatively underdeveloped. Although 'a cosy and friendly community', visitors' first impressions were 'rarely complimentary' and migrants often arrived with considerable misgivings about their new home. ${ }^{40}$ The city lacked a 'central focus', with suburbs seeming disconnected from each other and the 'unifying elements' present in Griffin's design still unrealised. ${ }^{41}$ Many buildings were intended to be temporary, while others had not begun to be constructed, and the advice of the NCPDC was frequently ignored or circumvented. ${ }^{42}$ The situation would soon change, however. In November 1954, a Senate select committee chaired by John McCallum was appointed to inquire into the development of the city. By this time, spurred by his wife Dame Pattie and daughter Heather Henderson, Prime Minister Robert Menzies, who had initially disliked Canberra intensely, had become one of the city's great champions, determined to ensure it became a place fit to be the national capital. ${ }^{43}$ The select committee's report was a 'turning point' for Canberra, for it led to the creation of the National Capital Development Commission (NCDC) in 1957. ${ }^{44}$ With (Sir) John Overall as commissioner, and Bill Andrews and Grenfell Rudduck as associate commissioners, the NCDC was tasked with continuing the development and building of the city. Peter Harrison became chief planner in 1959.

From this point, Canberra's development and expansion proceeded much more rapidly. Houses, offices, schools and other amenities sprang up, and with continuing transfers of public servants from Melbourne to Canberra, the city finally attained its position as the seat of federal government in practice as well as in name. New

\footnotetext{
39 Gibbney, Canberra 1913-1953, 167.

40 Gibbney, Canberra 1913-1953, 269-70.

41 Eric Sparke, Canberra 1954-1980 (Canberra: Australian Government Publishing Service, 1988), 1-2.

42 Sparke, Canberra 1954-1980, 3-11.

43 Sparke, Canberra 1954-1980, 31-32.

44 Sparke, Canberra 1954-1980, 50.
} 
public buildings were constructed in quick succession, among them the Reserve Bank, the Royal Australian Mint, the Canberra Theatre Centre and the Deep Space Tracking Station, located south of the city at Tidbinbilla. A variety of new embassies appeared, including those of France, Canada, Israel and Malaysia. With the completion of new roads and suburbs, Canberra also became more integrated, no longer a disparate collection of suburbs but a whole city, and one that was becoming increasingly sophisticated. Amenities increased, from restaurants to squash courts to traffic lights. ${ }^{45}$ And, after decades of disagreement as to the form that should be adopted for the ornamental lakes envisaged by Griffin, a design was at last settled and construction begun. The valves on the newly constructed Scrivener Dam were closed on 20 September 1963, and by the end of April the following year Lake Burley Griffin was filled. ${ }^{46}$

Having been well and truly set in motion, the city's development continued apace after the resignation from office of its champion, Menzies, in 1966. There was a new mood. Retiring from the position of director and manager of the Canberra Tourist Bureau in May 1968, J. C. Dovey reflected on the changes that had taken place since his arrival in the city 40 years before. Prior to the establishment of the NCDC, he said, 'Canberra was a place that did not know where it was going'. Dovey saw Canberra as 'a city of opportunity', and expected it would continue to grow. ${ }^{47}$ A monumental new National Library building, designed by Walter Bunning, was opened alongside the lake that year, the colossal spout of the Captain James Cook memorial fountain was inaugurated in 1970, and offices and suburbs continued to sprout across the landscape. In order to accommodate future growth, plans were adopted for a series of satellite towns, to be constructed in adjoining valleys, with ridges and hilltops maintained as areas of bush. ${ }^{48}$ By the early 1970s, Canberra had been transformed. The city's population had risen from 39,000 in 1958 to 155,000 in 1972, two new town centres had been settled in the Woden Valley and Belconnen, and in Gough Whitlam-the son of Fred Whitlam-the country for the first time had a prime minister who had lived in Canberra in his youth. ${ }^{49}$

\section{Reaching 100}

Canberra's rapid growth continued during the 1970s, with the population growing by 12,000 people per year in the first part of the decade, and significant pressure on housing. ${ }^{50}$ Another new town centre, Tuggeranong, was inaugurated in 1973, and

45 Sparke, Canberra 1954-1980, 101-5.

46 Sparke, Canberra 1954-1980, 131-41.

47 'Canberra "Not Ready Yet for Swinging Nightlife”, Canberra Times, 13 May 1968, 10.

48 Sparke, Canberra 1954-1980, 151.

49 Sparke, Canberra 1954-1980, 188.

50 Sparke, Canberra 1954-1980, 210-11, 234. 
work on a new dam, the Googong, began two years later. A decision with a major impact on the city was made in 1974, when the site for the new Parliament House was finally settled as Capital Hill. As elsewhere in the country, the decade also saw considerable social and political ferment. Eric Sparke observed that these years had 'something of the character of an Age of Dissent' in Canberra. ${ }^{51}$ Perhaps inspired by a nationwide mood of activism, Canberrans increasingly questioned plans made for the city's development and decisions taken on a range of projects.

Among other fights, considerable opposition was expressed to the erection of a telecommunications tower on Black Mountain. Objections were made on ecological as well as aesthetic grounds, and a Committee to Save Black Mountain was formed to resist the plan. In 1973, a group of demonstrators interrupted work on the tower's construction. ${ }^{52}$ Following a failed attempt to block the tower in the High Court of Australia, the tower was eventually opened, amid protests, by Prime Minister Malcolm Fraser in $1980 .{ }^{53}$ Resistance also occurred to the development of a casino in the city. Griffin's original design had included a casino, to have been placed where the Australian War Memorial was located. The casino mooted in the 1970s was not the pleasure garden envisaged by the Griffins, however, and it aroused a sizeable opposition. A committee formed to prevent its development, driven by moral concerns and by a belief that a casino would debase the national capital; the committee circulated a petition and delivered letters around Canberra homes. ${ }^{54}$ The casino plans were abandoned, though only temporarily, in August 1977.55

The capital was also the scene of demonstrations relating to nationwide issues. One of the most evocative acts of protest was the creation of an Aboriginal tent embassy in 1972. A response to Prime Minister William McMahon's 1972 Australia Day speech refusing to accept land rights, the embassy graphically displayed the feeling of many Aboriginal people, including from the Canberra region, that they had become aliens in their own land. ${ }^{56}$

Canberra's development slowed after the Liberal-Country Party coalition came to office under Prime Minister Malcolm Fraser in 1975, under the pressure of a struggling economy. ${ }^{57}$ In 1979 the Canberra Times reported that Fraser was soon to make '[a] major statement on the social and economic situation of the ACT', which faced 'record unemployment levels ... and a growing small-business

\footnotetext{
51 Sparke, Canberra 1954-1980, 245.

52 'Demonstrators Disrupt Work on Tower Site', Canberra Times, 22 September 1973, 1.

53 Peter George, 'Tower Project Backed by High Court', Canberra Times, 18 February 1975, 1; 'Protests as PM Opens Tower', Canberra Times, 16 May 1980, 1.

54 Sparke, Canberra 1954-1980, 267; 'Committee to Oppose Casino for ACT', Canberra Times, 22 July 1977, 7.

55 Ian Myerscough, 'Cabinet Bars Casino', Canberra Times, 4 August 1977, 1.

56 Bain Attwood, Rights for Aborigines (Crows Nest, NSW: Allen and Unwin, 2003), 345; Bain Attwood and Andrew Markus, The Struggle for Aboriginal Rights: A Documentary History (St Leonards, NSW: Allen and Unwin, 1999), 174.

57 Sparke, Canberra 1954-1980, 291-96.
} 
collapse..$^{58}$ Nevertheless, some large projects had continued. The National Gallery and the High Court were completed, work was undertaken towards the creation of a national museum and, most significantly, work was begun on the new, permanent Parliament House. A design competition was launched in April 1979, with the winner, Romaldo Giurgola, chosen the following year. The first sod was turned by Fraser on 18 September 1980. ${ }^{59}$

The new Parliament House opened in Australia’s Bicentennial year, 1988, just two years after Canberra's population had reached $250,000 .^{60}$ At the end of the year, the territory was given full self-government through an Act of the Commonwealth Parliament. The question of self-government had been considered as long ago as 1910, when a provision for the creation of a local legislature was removed from the Bill for the Seat of Government (Administration) Act. ${ }^{61}$ Different proposals for some form of self-government for the ACT were made at various times over the following decades, and eventually in 1985 a plan was determined and a timetable declared by Bob Hawke's Labor Government. ${ }^{62}$ The first election under self-government was held in March 1989, and a 17-member Legislative Assembly began sitting. In May the territory's first government was formed, and Chief Minister Rosemary Follett became the first woman head of government in Australia.

Another new town centre, Gungahlin, was launched in 1991, and through the 1990s and 2000s Canberra continued to grow and develop. In 2003, however, the city was hit by a terrible natural disaster, a devastating firestorm. Bushfires had been burning around the edge of the territory for over a week. On Saturday 18 January, a hot and windy day, the fires burned steadily closer to Canberra's outer suburbs, and a state of emergency was declared in mid-afternoon. Shortly after, the fires reached the city. In the hours that followed four people died, while more than 400 were injured and over 500 homes and businesses were lost, as well as buildings, telescopes and other infrastructure at the Mount Stromlo Observatory. In the aftermath of the fires, there was considerable controversy regarding failures in preparations and responses to the fire threat. Ten years after that terrible day, Canberra remembered its loss even as it celebrated its 100th year.

58 Ross Andrews and John Jesser, 'PM to Act Soon on Canberra's Problems', Canberra Times, 12 June 1979, 1.

59 Sparke, Canberra 1954-1980, 291-322.

60 Sparke, Canberra 1954-1980, 323; 'Seven Years to Build a House', Canberra Times, 9 May 1988, 44S.

61 Sparke, Canberra 1954-1980, 273.

62 Sparke, Canberra 1954-1980, 334-36; 'Town Council for ACT', Canberra Times, 3 December 1985, 1. 


\section{Conclusion}

In 2013 the city of Canberra celebrated its centenary with an avalanche of special events, publications, exhibitions and other commemorative activities. But as its history demonstrates, the choice of 2013 as its 100th birthday was in some ways an arbitrary one. The city was not simply 100 years old. Its beginning could be dated to 1911, when the Federal Capital Territory was declared, or to 1908, when the Yass-Canberra site was chosen. Further back, it was not quite 200 years since Europeans arrived to live in the region and a settlement known as Canberra-or Canberry or other variations-began to grow. And the Canberra region has a much longer history than that, with Aboriginal people occupying its hills and valleys for more than 20,000 years. The city has had several existences, often simultaneously: as federal capital and centre of the nation's political life; as quiet rural community; and as source of nourishment and life for its Aboriginal custodians. As a planned city, Canberra has evoked a range of reactions from those who have lived, worked and sojourned in it, and it has developed its own distinctive character. Its history is the product of many stories-local and national, personal and communal. As its centenary celebrations recede into the past, Canberra's story continues.

\section{Australian Dictionary of Biography entries used in the preparation of this article}

Allen, C. W., 'Duffield, Walter Geoffrey (1879-1929)', Australian Dictionary of Biography, National Centre of Biography, The Australian National University, adb.anu.edu.au/ biography/duffield-walter-geoffrey-6027/text10301, published first in hardcopy 1981.

Apperly, Richard E., and Peter Reynolds, 'Sulman, Sir John (1849-1934)', Australian Dictionary of Biography, National Centre of Biography, The Australian National University, adb.anu.edu.au/biography/sulman-sir-john-8714/text15255, published first in hardcopy 1990.

Bennett, J. M., 'Blacket, Wilfred (1859-1937)', Australian Dictionary of Biography, National Centre of Biography, The Australian National University, adb.anu.edu.au/biography/ blacket-wilfred-5260/text8865, published first in hardcopy 1979.

Birtles, Terry G., 'Scrivener, Charles Robert (1855-1923)', Australian Dictionary of Biography, National Centre of Biography, The Australian National University, adb.anu.edu.au/ biography/scrivener-charles-robert-8374/text14697, published first in hardcopy 1988.

Bridge, Carl, 'Page, Sir Earle Christmas (1880-1961)', Australian Dictionary of Biography, National Centre of Biography, The Australian National University, adb.anu.edu.au/ biography/page-sir-earle-christmas-7941/text13821, published first in hardcopy 1988. 
Brown, Nicholas, 'Dunk, Sir William Ernest (Bill) (1897-1984)', Australian Dictionary of Biography, National Centre of Biography, The Australian National University, adb. anu.edu.au/biography/dunk-sir-william-ernest-bill-12445/text22379, published first in hardcopy 2007.

Bygott, Ursula, 'Wallace, Sir Robert Strachan (1882-1961)', Australian Dictionary of Biography, National Centre of Biography, The Australian National University, adb.anu.edu.au/ biography/wallace-sir-robert-strachan-8962/text15767, published first in hardcopy 1990.

Cable, K. J., 'MacCallum, Sir Mungo William (1854-1942)', Australian Dictionary of Biography, National Centre of Biography, The Australian National University, adb.anu.edu. au/biography/maccallum-sir-mungo-william-7301/text12663, published first in hardcopy 1986.

Cain, Neville, 'Giblin, Lyndhurst Falkiner (1872-1951)', Australian Dictionary of Biography, National Centre of Biography, The Australian National University, adb.anu.edu.au/ biography/giblin-lyndhurst-falkiner-6303/text10871, published first in hardcopy 1981.

Carment, David, 'Groom, Sir Littleton Ernest (1867-1936)', Australian Dictionary of Biography, National Centre of Biography, The Australian National University, adb.anu. edu.au/biography/groom-sir-littleton-ernest-6499/text11145, published first in hardcopy 1983.

Carron, L. T., 'Lane-Poole, Charles Edward (1885-1970)', Australian Dictionary of Biography, National Centre of Biography, The Australian National University, adb.anu.edu.au/ biography/lane-poole-charles-edward-7026/text12221, published first in hardcopy 1983.

Clark, Chris, 'Bridges, Sir William Throsby (1861-1915)', Australian Dictionary of Biography, National Centre of Biography, The Australian National University, adb.anu.edu.au/ biography/bridges-sir-william-throsby-5355/text9055, published first in hardcopy 1979.

Clarke, Patricia, 'Tillyard, Pattie (1880-1971)', Australian Dictionary of Biography, National Centre of Biography, The Australian National University, adb.anu.edu.au/biography/ tillyard-pattie-8816/text15463, published first in hardcopy 1990.

'Cook, James (1728-1779)', Australian Dictionary of Biography, National Centre of Biography, The Australian National University, adb.anu.edu.au/biography/cookjames-1917/text2279, published first in hardcopy 1966.

Crowley, F. K., 'Cook, Sir Joseph (1860-1947)', Australian Dictionary of Biography, National Centre of Biography, The Australian National University, adb.anu.edu.au/biography/ cook-sir-joseph-5763/text9765, published first in hardcopy 1981.

Cunneen, Chris, 'Denman, Thomas (1874-1954)', Australian Dictionary of Biography, National Centre of Biography, The Australian National University, adb.anu.edu.au/ biography/denman-thomas-5956/text10161, published first in hardcopy 1981.

Cunneen, Chris, 'Lyne, Sir William John (1844-1913)', Australian Dictionary of Biography, National Centre of Biography, The Australian National University, adb.anu.edu.au/ biography/lyne-sir-william-john-7274/text12609, published first in hardcopy 1986. 
Davidson, Jim, 'Hancock, Sir William Keith (1898-1988)', Australian Dictionary of Biography, National Centre of Biography, The Australian National University, adb.anu.edu.au/ biography/hancock-sir-william-keith-460/text22673, published first in hardcopy 2007.

Davidson, Jim, 'Melba, Dame Nellie (1861-1931)', Australian Dictionary of Biography, National Centre of Biography, The Australian National University, adb.anu.edu.au/ biography/melba-dame-nellie-7551/text13175, published first in hardcopy 1986.

'de Salis, Leopold Fabius (1816-1898)', Australian Dictionary of Biography, National Centre of Biography, The Australian National University, adb.anu.edu.au/biography/de-salisleopold-fabius-3402/text5163, published first in hardcopy 1972.

Easson, Michael, 'McCallum, John Archibald (1892-1973)', Australian Dictionary of Biography, National Centre of Biography, The Australian National University, adb.anu. edu.au/biography/mccallum-john-archibald-10903/text19361, published first in hardcopy 2000 .

Faunce, Marcus De Laune, 'Faunce, Alured Tasker (1808-1856)', Australian Dictionary of Biography, National Centre of Biography, The Australian National University, adb. anu.edu.au/biography/faunce-alured-tasker-2036/text2515, published first in hardcopy 1966.

Fenner, Frank, 'Florey, Howard Walter (1898-1968)', Australian Dictionary of Biography, National Centre of Biography, The Australian National University, adb.anu.edu.au/ biography/florey-howard-walter-10206/text18037, published first in hardcopy 1996.

Fielding, Jean P., and J. H. Thyer, 'Chumleigh, Harold Vere (1880-1970)', Australian Dictionary of Biography, National Centre of Biography, The Australian National University, adb.anu.edu.au/biography/chumleigh-harold-vere-5592/text9505, published first in hardcopy 1979.

Fitzhardinge, L. F., 'Hughes, William Morris (Billy) (1862-1952)', Australian Dictionary of Biography, National Centre of Biography, The Australian National University, adb. anu.edu.au/biography/hughes-william-morris-billy-6761/text11689, published first in hardcopy 1983.

Fitzhardinge, L. F., 'Moore, Joshua John (1790-1864)', Australian Dictionary of Biography, National Centre of Biography, The Australian National University, adb.anu.edu.au/ biography/moore-joshua-john-2475/text3323, published first in hardcopy 1967.

Fitzpatrick, Dorothy, 'MacPherson, John Alexander (1833-1894)', Australian Dictionary of Biography, National Centre of Biography, The Australian National University, adb. anu.edu.au/biography/macpherson-john-alexander-4135/text6621, published first in hardcopy 1974.

Gibbney, H. J., 'Chapman, Sir Austin (1864-1926)', Australian Dictionary of Biography, National Centre of Biography, The Australian National University, adb.anu.edu.au/ biography/chapman-sir-austin-5554/text9469, published first in hardcopy 1979. 
Gibbney, H. J., 'Shakespeare, Arthur Thomas (1897-1975)', Australian Dictionary of Biography, National Centre of Biography, The Australian National University, adb.anu.edu.au/ biography/shakespeare-arthur-thomas-8525/text14737, published first in hardcopy 1988.

Grey, Jeffrey, 'White, Sir Cyril Brudenell (1876-1940)', Australian Dictionary of Biography, National Centre of Biography, The Australian National University, adb.anu.edu.au/ biography/white-sir-cyril-brudenell-1032/text15983, published first in hardcopy 1990.

Hardie, M. F., 'Oliver, Alexander (1832-1904)', Australian Dictionary of Biography, National Centre of Biography, The Australian National University, adb.anu.edu.au/biography/ oliver-alexander-4329/text7025, published first in hardcopy 1974.

Harrison, Peter, 'Daley, Charles Studdy (1887-1966)', Australian Dictionary of Biography, National Centre of Biography, The Australian National University, adb.anu.edu.au/ biography/daley-charles-studdy-5865/text9975, published first in hardcopy 1981.

Harrison, Peter, 'Griffin, Walter Burley (1876-1937)', Australian Dictionary of Biography, National Centre of Biography, The Australian National University, adb.anu.edu.au/ biography/griffin-walter-burley-443/text11115, published first in hardcopy 1983.

Harrison, Peter, 'Miller, David (1857-1934)', Australian Dictionary of Biography, National Centre of Biography, The Australian National University, adb.anu.edu.au/biography/ miller-david-7580/text13233, published first in hardcopy 1986.

Hazlehurst, Cameron, 'Street, Geoffrey Austin (1894-1940)', Australian Dictionary of Biography, National Centre of Biography, The Australian National University, adb.anu. edu.au/biography/street-geoffrey-austin-946/text15215, published first in hardcopy 1990.

Hazlehurst, Cameron, 'Whitlam, Harry Frederick (Fred) (1884-1961)', Australian Dictionary of Biography, National Centre of Biography, The Australian National University, adb. anu.edu.au/biography/whitlam-harry-frederick-fred-12020/text21559, published first in hardcopy 2002.

Hill, A. J., 'Gullett, Sir Henry Somer (Harry) (1878-1940)', Australian Dictionary of Biography, National Centre of Biography, The Australian National University, adb. anu.edu.au/biography/gullett-sir-henry-somer-harry-448/text11157, published first in hardcopy 1983.

Hill, A. J., 'Ryrie, Sir Granville de Laune (1865-1937)', Australian Dictionary of Biography, National Centre of Biography, The Australian National University, adb.anu.edu.au/ biography/ryrie-sir-granville-de-laune-8319/text14593, published first in hardcopy 1988.

Hoyle, Arthur, 'O’Malley, King (1858-1953)', Australian Dictionary of Biography, National Centre of Biography, The Australian National University, adb.anu.edu.au/biography/ omalley-king-7907/text13753, published first in hardcopy 1988.

Inglis, K. S., 'Bean, Charles Edwin (1879-1968)', Australian Dictionary of Biography, National Centre of Biography, The Australian National University, adb.anu.edu.au/ biography/bean-charles-edwin-5166/text8677, published first in hardcopy 1979. 
Johnson, Donald H., 'Macartney, Henry Dundas (1880-1932)', Australian Dictionary of Biography, National Centre of Biography, The Australian National University, adb.anu. edu.au/biography/macartney-henry-dundas-7291/text12645, published first in hardcopy 1986.

Langmore, Diane, 'Menzies, Dame Pattie Maie (1899-1995)', Australian Dictionary of Biography, National Centre of Biography, The Australian National University, adb.anu. edu.au/biography/menzies-dame-pattie-maie-27340/text34803, published online 2019.

Lea-Scarlett, E. J., 'Gale, John (1831-1929)', Australian Dictionary of Biography, National Centre of Biography, The Australian National University, adb.anu.edu.au/biography/ gale-john-3586/text5555, published first in hardcopy 1972 .

Leeser, Julian, 'McMahon, Sir William (Billy) (1908-1988)', Australian Dictionary of Biography, National Centre of Biography, The Australian National University, adb. anu.edu.au/biography/momahon-sir-william-billy-15043/text26240, published first in hardcopy 2012.

Linge, G. J. R., 'Butters, Sir John Henry (1885-1969)', Australian Dictionary of Biography, National Centre of Biography, The Australian National University, adb.anu.edu.au/ biography/butters-sir-john-henry-5454/text9263, published first in hardcopy 1979.

Malone, Stephen, 'Kirkpatrick, John (1856-1923)', Australian Dictionary of Biography, National Centre of Biography, The Australian National University, adb.anu.edu.au/ biography/kirkpatrick-john-6974/text12117, published first in hardcopy 1983.

Martin, A. W., 'Menzies, Sir Robert Gordon (Bob) (1894-1978)', Australian Dictionary of Biography, National Centre of Biography, The Australian National University, adb.anu. edu.au/biography/menzies-sir-robert-gordon-bob-11111/text19783, published first in hardcopy 2000.

McDonald, D. I., 'McLaren, Sir John Gilbert (1871-1958)', Australian Dictionary of Biography, National Centre of Biography, The Australian National University, adb.anu. edu.au/biography/mclaren-sir-john-gilbert-7408/text12885, published first in hardcopy 1986.

McDonald, D. I., 'Murdoch, John Smith (1862-1945)', Australian Dictionary of Biography, National Centre of Biography, The Australian National University, adb.anu.edu.au/ biography/murdoch-john-smith-7692/text13465, published first in hardcopy 1986.

McNicoll, Ronald, 'Owen, Percy Thomas (1864-1936)', Australian Dictionary of Biography, National Centre of Biography, The Australian National University, adb.anu.edu.au/ biography/owen-percy-thomas-8498/text13811, published first in hardcopy 1988.

Morison, Ian W., 'Rudduck, Grenfell (1914-1964)', Australian Dictionary of Biography, National Centre of Biography, The Australian National University, adb.anu.edu.au/ biography/rudduck-grenfell-11583/text20677, published first in hardcopy 2002. 
Murphy, D. J., 'Fisher, Andrew (1862-1928)', Australian Dictionary of Biography, National Centre of Biography, The Australian National University, adb.anu.edu.au/biography/ fisher-andrew-378/text10613, published first in hardcopy 1981.

Nairn, Bede, 'Watson, John Christian (Chris) (1867-1941)', Australian Dictionary of Biography, National Centre of Biography, The Australian National University, adb. anu.edu.au/biography/watson-john-christian-chris-9003/text15849, published first in hardcopy 1990.

Newman, C. E. T., 'Campbell, Charles (1810-1888)', Australian Dictionary of Biography, National Centre of Biography, The Australian National University, adb.anu.edu.au/ biography/campbell-charles-1871/text2187, published first in hardcopy 1966.

Norris, K. R., and D. F. Waterhouse, 'Tillyard, Robin John (1881-1937)', Australian Dictionary of Biography, National Centre of Biography, The Australian National University, adb.anu.edu.au/biography/tillyard-robin-john-8817/text15465, published first in hardcopy 1990.

Norris, R., 'Deakin, Alfred (1856-1919)', Australian Dictionary of Biography, National Centre of Biography, The Australian National University, adb.anu.edu.au/biography/ deakin-alfred-5927/text10099, published first in hardcopy 1981.

Parker, R. S., 'Garran, Sir Robert Randolph (1867-1957)', Australian Dictionary of Biography, National Centre of Biography, The Australian National University, adb.anu.edu.au/ biography/garran-sir-robert-randolph-410/text10827, published first in hardcopy 1981.

Parsons, Vivienne, 'Throsby, Charles (1777-1828)', Australian Dictionary of Biography, National Centre of Biography, The Australian National University, adb.anu.edu.au/ biography/throsby-charles-2735/text3861, published first in hardcopy 1967.

Parsons, Vivienne, 'Wild, Joseph (1773-1847)', Australian Dictionary of Biography, National Centre of Biography, The Australian National University, adb.anu.edu.au/biography/ wild-joseph-2791/text3979, published first in hardcopy 1967.

Persse, Michael D. De B. Collins, 'Fairbairn, James Valentine (Jim) (1897-1940)', Australian Dictionary of Biography, National Centre of Biography, The Australian National University, adb.anu.edu.au/biography/fairbairn-james-valentine-jim-364/text10519, published first in hardcopy 1981.

Phillips, Nan, 'Clarke, Thomas (1840-1867)', Australian Dictionary of Biography, National Centre of Biography, The Australian National University, adb.anu.edu.au/biography/ clarke-thomas-3226/text4861, published first in hardcopy 1969.

Poulos, Judy, 'Andrews, William Charles (Bill) (1908-1988)', Australian Dictionary of Biography, National Centre of Biography, The Australian National University, adb.anu.edu. au/biography/andrews-william-charles-bill-12140/text21751, published first in hardcopy 2007. 
Radi, Heather, 'Bruce, Stanley Melbourne (1883-1967)', Australian Dictionary of Biography, National Centre of Biography, The Australian National University, adb.anu.edu.au/ biography/bruce-stanley-melbourne-5400/text9147, published first in hardcopy 1979.

Richardson, Jack E., 'Bailey, Sir Kenneth Hamilton (1898-1972)', Australian Dictionary of Biography, National Centre of Biography, The Australian National University, adb. anu.edu.au/biography/bailey-sir-kenneth-hamilton-9404/text16529, published first in hardcopy 1993.

Rutledge, Martha, 'Kelly, William Henry (1877-1960)', Australian Dictionary of Biography, National Centre of Biography, The Australian National University, adb.anu.edu.au/ biography/kelly-william-henry-7091/text12017, published first in hardcopy 1983.

Southern, Roger J., 'Coane, John Montgomery (1848-1923)', Australian Dictionary of Biography, National Centre of Biography, The Australian National University, adb.anu. edu.au/biography/coane-john-montgomery-5692/text9621, published first in hardcopy 1981.

Spearritt, Peter, 'Bunning, Walter Ralston (1912-1977)', Australian Dictionary of Biography, National Centre of Biography, The Australian National University, adb.anu.edu.au/ biography/bunning-walter-ralston-9623/text16969, published first in hardcopy 1993.

Steven, Margaret, 'Campbell, Robert (1769-1846)', Australian Dictionary of Biography, National Centre of Biography, The Australian National University, adb.anu.edu.au/ biography/campbell-robert-1876/text2197, published first in hardcopy 1966.

Steven, Margaret, 'Palmer, George Thomas (1784-1854)', Australian Dictionary of Biography, National Centre of Biography, The Australian National University, adb.anu.edu.au/ biography/palmer-george-thomas-2532/text3435, published first in hardcopy 1967.

Steven, Margaret, 'Palmer, John (1760-1833)', Australian Dictionary of Biography, National Centre of Biography, The Australian National University, adb.anu.edu.au/biography/ palmer-john-2533/text3437, published first in hardcopy 1967.

Troy, P. N., 'Harrison, Peter Firman (1918-1990)', Australian Dictionary of Biography, National Centre of Biography, The Australian National University, adb.anu.edu.au/ biography/harrison-peter-firman-12596/text22687, published first in hardcopy 2007.

Walsh, G. P., 'Lasseter, Lewis Hubert (1880-1931)', Australian Dictionary of Biography, National Centre of Biography, The Australian National University, adb.anu.edu.au/ biography/lasseter-lewis-hubert-7039/text12247, published first in hardcopy 1983.

Ward, John M., 'Wade, Sir Charles Gregory (1863-1922)', Australian Dictionary of Biography, National Centre of Biography, The Australian National University, adb.anu. edu.au/biography/wade-sir-charles-gregory-8938/text15707, published first in hardcopy 1990. 
Whitlam, E. G., 'Knowles, Sir George Shaw (1882-1947)', Australian Dictionary of Biography, National Centre of Biography, The Australian National University, adb.anu. edu.au/biography/knowles-sir-george-shaw-6987/text12145, published first in hardcopy 1983.

Wilson, Gwendoline, 'Murray, Sir Terence Aubrey (1810-1873)', Australian Dictionary of Biography, National Centre of Biography, The Australian National University, adb. anu.edu.au/biography/murray-sir-terence-aubrey-2498/text3369, published first in hardcopy 1967.

Wrigley, C. W., 'Farrer, William James (1845-1906)', Australian Dictionary of Biography, National Centre of Biography, The Australian National University, adb.anu.edu.au/ biography/farrer-william-james-6145/text10549, published first in hardcopy 1981.

\section{Obituaries Australia entries used in the preparation of this article}

'Campbell, Frederick Arthur (Fred) (1846-1928)', Obituaries Australia, National Centre of Biography, The Australian National University, oa.anu.edu.au/obituary/campbellfrederick-arthur-fred-23898/text32743.

Carver, John, 'Oliphant, Sir Marcus Laurence (Mark) (1901-2000)', Obituaries Australia, National Centre of Biography, The Australian National University, oa.anu.edu.au/ obituary/oliphant-sir-marcus-laurence-mark-782/text783.

'Cavanagh, Mary (1840-1921)', Obituaries Australia, National Centre of Biography, The Australian National University, oa.anu.edu.au/obituary/cavanagh-mary-14611/ text25738.

'Cavanagh, Patrick (1832-1914)', Obituaries Australia, National Centre of Biography, The Australian National University, oa.anu.edu.au/obituary/cavanagh-patrick-14613/ text 25740 .

'Cunningham, Andrew Jackson (1839-1913)', Obituaries Australia, National Centre of Biography, The Australian National University, oa.anu.edu.au/obituary/cunninghamandrew-jackson-275/text1746.

'Cunningham, James (Jim) (1850-1921)', Obituaries Australia, National Centre of Biography, The Australian National University, oa.anu.edu.au/obituary/cunningham-james-jim-278/ text 1745 .

Farquharson, John, 'Fraser, Malcolm (1930-2015)', Obituaries Australia, National Centre of Biography, The Australian National University, oa.anu.edu.au/obituary/frasermalcolm-19633/text30952.

'Hayley, William Foxton (1814-1878)', Obituaries Australia, National Centre of Biography, The Australian National University, oa.anu.edu.au/obituary/hayley-williamfoxton-14544/text25655. 
'Margules, Stanley Raymond (Ray) (1926-2013)', Obituaries Australia, National Centre of Biography, The Australian National University, oa.anu.edu.au/obituary/margulesstanley-raymond-ray-18373/text30013.

Persse, Michael, 'Campbell, Charles Arthur (1937-2011)', Obituaries Australia, National Centre of Biography, The Australian National University, oa.anu.edu.au/obituary/ campbell-charles-arthur-17862/text29450.

'Scannell, Michael John (1887-1949)', Obituaries Australia, National Centre of Biography, The Australian National University, oa.anu.edu.au/obituary/scannell-michaeljohn-14277/text25338.

'Sibrey, James Benjamin (1841-1892)', Obituaries Australia, National Centre of Biography, The Australian National University, oa.anu.edu.au/obituary/sibrey-james-benjamin24436/text33164.

Smith, Fred, 'Ward, Barnaby Charles (1969-2002)', Obituaries Australia, National Centre of Biography, The Australian National University, oa.anu.edu.au/obituary/ward-barnabycharles-13976/text24895.

Stephens, Tony, 'Whitlam, Edward Gough (1916-2014)', Obituaries Australia, National Centre of Biography, The Australian National University, oa.anu.edu.au/obituary/ whitlam-edward-gough-18730/text30330.

'Taylor, John (Johnny) (1850-1875)', Obituaries Australia, National Centre of Biography, The Australian National University, oa.anu.edu.au/obituary/taylor-john-johnny-14342/ text25413. 
This text is taken from Australian Journal of Biography and History: No. 2, 2019, published 2019 by ANU Press, The Australian National University, Canberra, Australia.

doi.org/10.22459/AJBH.2019.02 